\title{
Prevalence of hypohydration in adolescents during the school day in Cyprus: seasonal variations
}

Pinelopi S. Stavrinou, ${ }^{1}$ Christoforos D. Giannaki, ${ }^{1}$ Eleni Andreou ${ }^{1}$ and George Aphamis ${ }^{1}$

${ }^{1}$ Department of Life and Health Sciences, University of Nicosia, Nicosia, Cyprus. (Correspondence to: Pinelopi S. Stavrinou: stavrinou.p@unic.ac.cy).

\begin{abstract}
Background: Evidence on the hydration status of adolescents and seasonal and time variations is scarce.

Aims: This study aimed to assess variations in the hydration status and total water intake of adolescents in Cyprus between winter and summer and between the morning and end of the school day. Subjective feelings and cognitive function associated with hypohydration were also examined.
\end{abstract}

Methods: Fifty-three adolescents (39 boys) with a mean age (standard deviation, SD) of 15.1 (1.9) years were included in the study. Participants provided urine samples and completed a cognitive function test and a questionnaire on subjective feelings upon arrival at school and at the end of the school day. Data were collected in winter and summer in 2016-2017. Hydration level was determined by urine specific gravity and cognitive function was assessed with a symbol cancellation test. Total water intake was estimated from a food and fluid record kept by the participants.

Results: A high prevalence of hypohydration was found in both seasons ranging from $72 \%$ to $94 \%$. Hypohydration was associated with perceptions of lower concentration and alertness $(P=0.008$ and $P=0.047$, respectively). Adolescents had significantly higher mean urine specific gravity in winter than in summer: 1.026 (SD 0.007) versus 1.023 (SD 0.007), respectively $(P=0.002)$. Hydration status was not associated with cognitive function or total water intake.

Conclusions: The high prevalence of hypohydration and the associated feelings of lower concentration and alertness in adolescents suggests that educational measures are needed to promote good drinking behaviour and improve hydration. Keywords: adolescents, cognitive function, hydration, water intake, Cyprus

Citation: Stavrinou SP; Giannaki DC; Andreou E; Aphamis G. Prevalence of hypohydration in adolescents during the school day in Cyprus: seasonal variations. East Mediterr Health J. 2020;26(9):1034-1041. https://doi.org/10.26719/emhj.20.014

Received: 27/03/19; accepted: 19/08/19

Copyright $\odot$ World Health Organization (WHO) 2020. Open Access. Some rights reserved. This work is available under the CC BY-NC-SA 3.0 IGO

license (https://creativecommons.org/licenses/by-nc-sa/3.o/igo)

\section{Introduction}

Body water is tightly regulated and daily fluctuations are maintained around $0.5 \%$ of body mass even in hot weather conditions. Water is essential for cellular homeostasis as well as for thermoregulation of the human body (1). Hydration status reflects the balance between water intake and loss (2). Body water content deficit beyond the normal fluctuation is called hypohydration (3) and is associated with a number of negative effects on health (4). Fluid restriction leading to hypohydration has been shown to be associated with increased feelings of fatigue, decreased alertness and concentration, and lower levels of vigour/activity $(5,6)$. Cognitive function has also been shown to be negatively affected by low hydration status (7), especially when combined with heat stress (8). Children with hypohydration living in a warm climate have been shown to perform more poorly in cognitive tests (9), while children's performance in cognitive tasks appears to improve after drinking water (10).

Many children appear to have a low hydration status at some point during a typical school day $(11,12)$. Water intake and drinking behaviour of children and adolescents varies substantially between countries and most studies have been done in countries with a temperate climate, or outside summer months $(12,13)$. In addition, data on hydration in adolescents are scarce.
Living in a hot climate increases water loss and the risk of dehydration (14). Adolescents living in the eastern Mediterranean may face a higher risk of water loss and dehydration, as this area is characterized by mild winters and hot summers. School in Cyprus starts early in the morning and ends at 13:30 when the temperature exceeds $30{ }^{\circ} \mathrm{C}$ from April-May onwards. If adolescents fail to maintain a normal level of hydration (euhydration), their overall health, concentration and cognitive performance at school could be adversely affected $(9,11,15,16)$.

The primary aims of our study were to compare hydration status of adolescents and total water intake from fluids and solid food during school hours between winter and summer. Our secondary aim was to investigate the relationship between hydration status and cognitive function and subjective feelings relevant to hypohydration.

\section{Methods}

Fifty-three adolescents from three main cities of Cyprus (39 boys) volunteered for the study. Their mean age and standard deviation(SD) was 15.1(1.9) years, mean height was $165($ SD 10) $\mathrm{cm}$, mean body mass was 55.7 (SD 13.1) $\mathrm{kg}$ and mean body mass index was 20.4 (SD 3.4) $\mathrm{kg} / \mathrm{m}^{2}$. The study was carried out between 
2016 and 2017. Data were collected on two occasions, once in the winter time (February) and once in the summer time (during the first two weeks of June - the end of the school year), in random order to avoid any potential learning effect. Half of the participants provided data first in winter and then in summer, and the other half gave data first in the summer and then in the winter. This way we aimed to avoid potential learning effect on the cognitive tests, and any changes in drinking behaviour following the first set of data collection. On each occasion data were collected in the morning, at the beginning of the school day (about 07:30) and at the end of the school day (about 13:30). The outdoor temperature was measured to the nearest $0.1{ }^{\circ} \mathrm{C}$ using a portable hygro thermometer (Radiance Instruments Ltd, Hong Kong). The temperature ranged between $10{ }^{\circ} \mathrm{C}$ and $15{ }^{\circ} \mathrm{C}$ from morning to $13: 30$ during the winter period, and between $26^{\circ} \mathrm{C}$ and $30^{\circ} \mathrm{C}$ during the summer period.

\section{Hydration level assessment}

Hydration level was assessed by urine specific gravity from the first morning void and from one sample at the end of the school day, before leaving the school premises. Urine collection bottles $(60 \mathrm{~mL})$ were given to the participating students at the appropriate time. Urine specific gravity was determined shortly after urine collection and the remaining urine samples were immediately disposed of by the researchers. Urine specific gravity was assessed using a urine refractometer (DIGIT 0-12, Medline Scientific Limited, United Kingdom of Great Britain and Northern Ireland). The participants were then assigned into three groups according to their urine specific gravity level: euhydrated (urine specific gravity < 1.020), slightly hypohydrated (urine specific gravity 1.020-1.029) and very hypohydrated (urine specific gravity $\geq 1.030$ ) (3).

\section{Total water intake assessment}

Total water intake was estimated from both solid food and fluid intake. Upon arrival at school, the participants were provided with a food-and-fluid record on which they were asked to record in detail all solid food and all fluid intakes from the time they woke up until the end of the school day. Before the data collection day, all participants had attended an educational session on how to keep a detailed food-and-fluid record, which was organized and delivered by a registered dietitian. Morning water intake at home (before coming to school) and total water intake (from waking up and during the time that the students were at school) was estimated using DietPlan6 software (Forestfield Software Ltd, Horsham, United Kingdom), which accesses food tables from multiple sources. This software allows insertion of additional data from any source, any recipe, menu or personal food diary without restriction.

\section{Subjective feelings assessment}

The participants completed a subjective feelings questionnaire as described in detail elsewhere (5). Participants self-graded their feelings on an arbitrary linear scale ranging from o (not at all) to $100 \mathrm{~mm}$ (very much), to questions such as - how thirsty do you feel now? We assessed the following subjective feelings: thirst, dry mouth, fatigue, head numbness, ability to concentrate and alertness. The reliability and validity of visual analogue scales in assessment of subjective feelings have been previously shown (17).

\section{Cognitive function assessment}

We assessed cognitive function with a symbol cancellation test (18), where the participants were asked to identify 60 target stimuli that were embedded in a background of over 300 distractor stimuli. The participants were allowed $45 \mathrm{~s}$ to cross through as many targets as they could, while ignoring distractors. We marked each target omission or incorrectly identified distractor as 1 error point. The test was scored on the number of errors/omissions.

\section{Statistical analysis}

We used two-way repeated-measures ANOVA(season $\times$ time) and post-hoc tests with the Bonferroni correction to compare the variables measured. We compared hydration groups using one-way ANOVA with Tukey post-hoc test. We used SPSS, version 20 for all statistical analyses. All data are reported as mean (SD). Statistical significance was set at $P<0.05$.

\section{Ethical considerations}

We conducted our study according to the guidelines laid down in the Declaration of Helsinki (as revised in 2013). We obtained ethical approval for the study from the national bioethics committee (EЕBK/EП/2016/12). We obtained parental approval and written informed consent from the adolescents.

\section{Results}

\section{Subjective feelings, water intake and cognitive function}

With regard to urine specific gravity, the two-way repeated measures ANOVA showed significant differences between season $(P=0.002)$ and time $(P=0.046)$. A post-hoc Bonferroni analysis showed a higher urine specific gravity in the morning in winter compared with the end of the school day $(P=0.030)$ and compared with the morning in the summer period $(P=0.001)$ (Figure 1).

Subjective feelings and water intake during the winter and summer periods in the morning and at the end of the school day are shown in Table 1. Participants felt less thirsty $(P=0.039)$ and less fatigued $(P=0.022)$ in the winter compared with the summer. Participants felt more fatigued at the end of the school day than in the morning $(P=0.031)$; the post-hoc tests showed that the participants felt more fatigued at the end of the school day than in the morning in winter $(P=0.043)$. We found no significant difference in cognitive function between seasons. However, the participants performed better on cognitive function tests at the end of the school day than in the morning in both seasons $(P<0.001)$. We found no significant seasonal effect for total water intake. 
Figure 1 Urine specific gravity (USG) during winter and summer in the morning and at the end of the school day. Difference in the morning in winter compared with in summer $(P=0.001)$. Difference in the morning in winter compared with the end of the school day $(P=\mathbf{0 . 0 3 0})$.

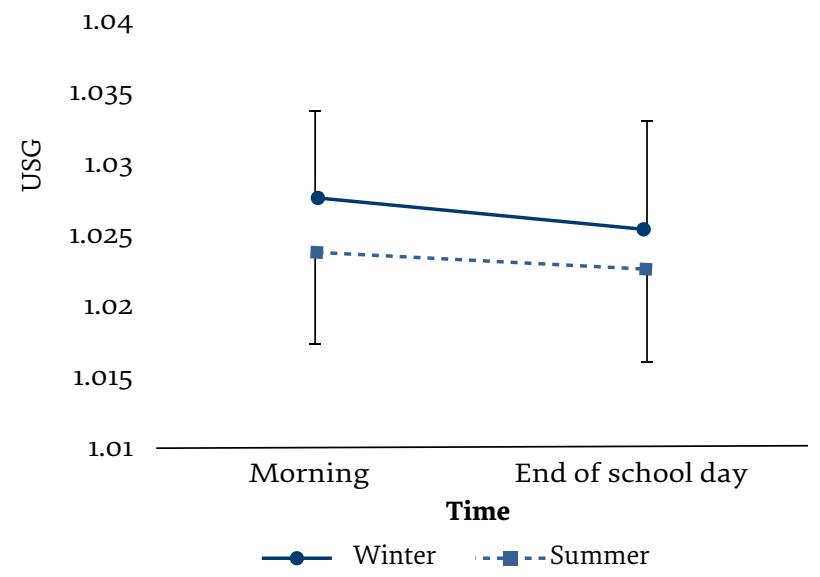

However total water intake was significantly higher at the end of the school day than in the morning in both seasons $(P<0.001)$.

\section{Hydration status}

During the winter period, more adolescents were very hypohydrated and fewer adolescents were hydrated than the summer period in the morning and at the end of the school day (Table 2).

Table 3 shows the effect of hydration status on subjective feelings and cognitive function. Hydration status significantly affected concentration and alertness, with participants who were euhydrated having better scores $(P<0.05)$. Euhydrated participants also had lower scores for feelings of dry mouth. Cognitive function did not differ between the categories of hydration status $(P>0.05)$. No significant difference was found between the total water intake and the hydration status categories in the morning and at the end of the school day, independently of season (Table 4).

\section{Discussion}

The main finding of our study was that adolescents had a higher urine specific gravity during the winter period compared with the summer period, with no difference in total water intake between the seasons. We found a high prevalence of raised urine specific gravity in both seasons. In addition, hydration status had a significant negative affect on perceived feelings of concentration and alertness. However, we found no association between hydration status and cognitive function.

The evaluation of seasonal variations on urine specific gravity was one of the main aims of our study. In the literature, data on seasonal variations are scarce and we aimed to add to the available knowledge. Cyprus has a Mediterranean climate with mild winters and hot summers and one would assume that the hot weather would induce more dehydration (19). Moreover, the high temperatures in Cyprus during the summer could lead to greater water loss through sweating and more thermal stress which would be expected to lead to higher fluid intake. However, our results show that adolescents in Cyprus had a higher urine specific gravity - indicating potentially more hypohydration - during the winter period than the summer period, as well as similar total water intake. Physiologically, dehydration occurs through passive exposure to a hot environment, exercise, or water restriction (20). It could be hypothesized that children were more physically active during school time in the winter, when the temperature is around $15^{\circ} \mathrm{C}$, and physical activity could decline in hot weather (21), especially in the Middle East (22). Despite this hypothesis, the etiology behind the higher urine specific gravity in the winter needs to be investigated. However, the above finding should be interpreted with caution, as urine specific gravity in both seasons indicated

Table 1 Subjective feelings, water intake and cognitive function in winter and summer, in the morning and at the end of the school day

\begin{tabular}{|c|c|c|c|c|c|c|}
\hline \multirow[t]{2}{*}{ Variable } & \multicolumn{2}{|c|}{ Winter } & \multicolumn{2}{|c|}{ Summer } & \multirow{2}{*}{$\begin{array}{c}\text { Seasonal effect } \\
\text { P-value }^{\mathrm{a}}\end{array}$} & \multirow{2}{*}{$\begin{array}{c}\text { Time effect } \\
\text { P-value }^{\mathrm{a}}\end{array}$} \\
\hline & Morning & $\begin{array}{l}\text { End of school } \\
\text { day }\end{array}$ & Morning & $\begin{array}{l}\text { End of school } \\
\text { day }\end{array}$ & & \\
\hline \multicolumn{7}{|l|}{ Subjective feeling of } \\
\hline Thirst & $3.7(1.8)$ & $3.0(2.2)$ & $4.1(2.3)$ & $4.1(3.0)$ & 0.039 & 0.369 \\
\hline Dry mouth & $3.7(2.3)$ & $3.4(1.8)$ & $3.7(2.1)$ & $3.8(3.0)$ & 0.495 & 0.814 \\
\hline Head numbness & $1.5(1.6)$ & $1.6(1.9)$ & $1.8(2.0)$ & $2.6(2.7)$ & 0.062 & 0.222 \\
\hline Concentration & $5.7(1.9)$ & $6.3(2.5)$ & $6.4(2.5)$ & $6.0(2.5)$ & 0.568 & 0.745 \\
\hline Fatigue & $2.7(2.2)$ & $3.6(2.2)$ & $3.6(2.5)$ & $4.3(2.9)$ & 0.022 & 0.031 \\
\hline Alertness & $5.5(2.4)$ & $6.6(2.2)$ & $5.8(2.2)$ & $5.7(2.1)$ & 0.372 & 0.150 \\
\hline Water intake (mL) & $203.0(199.2)$ & $856.0(524.7)$ & $174.1(175.6)$ & $891.8(524.8)$ & 0.950 & $<0.001$ \\
\hline $\begin{array}{l}\text { Cognitive function (no. of } \\
\text { errors) }\end{array}$ & $10(9)$ & $6(5)$ & $11(10)$ & $6(5)$ & 0.729 & $<0.001$ \\
\hline
\end{tabular}

${ }^{a}$ P-values in bold indicate significant seasonal and time effects at $P<0.05$.

Values shown are means (standard deviations). 
Table 2 Distribution of participants $(n=53)$ according to hydration status in winter and summer, in the morning and at the end of the school day

\begin{tabular}{lcccc} 
Hydration status $^{\mathrm{a}}$ & Worning & $\begin{array}{c}\text { Winter } \\
\text { End of the school } \\
\text { day }\end{array}$ & Morning & $\begin{array}{c}\text { Summer } \\
\text { End of the school } \\
\text { day }\end{array}$ \\
Euhydrated & No. & No. & No. & No. \\
Slightly hypohydrated & 3 & 21 & 11 & 15 \\
Very hypohydrated & 26 & 23 & 35 & 26 \\
\hline
\end{tabular}

${ }^{a}$ Euhydrated: urine specific gravity<1.020; slightly hypohydrated: urine specific gravity 1.020-1.029; very hypohydrated: urine specific gravity $\geq 1.030$.

slight hypohydration, and the statistical finding on urine specific gravity might not translate into a real physiological or clinical finding.

Our results clearly indicate a high prevalence of raised urine specific gravity; most of the adolescents had raised urine specific gravity in both winter and summer, in the morning and at the end of the school day, with nearly half of them having extremely high urine specific gravity and being potentially very hypohydrated. The prevalence of dehydration in children has been shown to be high in many countries regardless of the climate $(9,11,12)$. However, data on adolescent dehydration are scarce compared with other populations $(23,24)$. Evaluating hydration status, especially in children and adolescents, is important because dehydration has been suggested to have adverse effects on general health (4). More specifically in adolescents, acute dehydration may negatively affect brain function (13). Therefore, more studies are needed to evaluate adolescent health in relation to their hydration status.

According to our study, many adolescents arrive at school hypohydrated and remain so for the duration of the school day, both in winter and summer. These findings are in agreement with previous findings from countries where climate conditions are similar to Cyprus $(9,11)$. One could argue that urine specific gravity measured at the end of the school day could have been affected by food and fluid intake both at breakfast and during school hours. Research has shown that $600 \mathrm{~mL}$ of water can restore urine specific gravity to $<1.020$ within $40 \mathrm{~min}$ (25). Our participants had 174 and $203 \mathrm{~mL}$ of water intake in the morning in summer and winter, respectively, and less than $1 \mathrm{~L}$ of water during the school day. This was apparently inadequate to restore urine specific gravity as evidenced by the high urine specific gravity at the end of the school day. Even though a statistically significant reduction in urine specific gravity was found at the end of the school day compared with the morning, urine specific gravity values remained high and indicated slight hypohydration status. Therefore it appears that adolescents do not drink enough to restore euhydration during their time at school.

Most people rely on the sensation of thirst to prompt them to drink fluids (26). However, even though our participants had an increased feeling of thirst during the summer period, this perception was insufficient and did not lead to higher total water intake. It has been suggested that ratings of thirst perception do not always show predictable patterns of voluntary drinking following dehydration (26); this is probably because the sense of thirst is not an adequate reflection of the water

Table 3 Urine specific gravity, subjective feelings and cognitive function according to hydration status, independent of season and time

\begin{tabular}{|c|c|c|c|c|}
\hline Variable & Euhydrated $^{a}$ & Slightly hypohydrated ${ }^{a}$ & Very hypohydrated ${ }^{a}$ & P-value ${ }^{b}$ \\
\hline Urine specific gravity & $1.013(0.005)^{\mathrm{cd}}$ & $1.025(0.003)^{d}$ & $1.032(0.002)$ & $<0.001$ \\
\hline \multicolumn{5}{|l|}{ Subjective feelings } \\
\hline Thirst & $3.2(2)$ & $3.7(2.7)$ & $4.4(2.5)$ & 0.069 \\
\hline Dry mouth & $2.8(1.9)^{\mathrm{d}}$ & $3.5(2.6)^{d}$ & $4.5(2.5)$ & 0.009 \\
\hline Head numbness & $2.2(2.6)$ & $1.7(2)$ & $2.2(2.3)$ & 0.246 \\
\hline Concentration & $7.4(2.1)^{\mathrm{cd}}$ & $5.9(2.5)$ & $5.8(2.4)$ & 0.008 \\
\hline Fatigue & $3.2(2.4)$ & $3.4(2.7)$ & $4.2(2.7)$ & 0.164 \\
\hline Alertness & $6.8(2.2)^{\mathrm{d}}$ & $6.2(2.4)$ & $5.5(2.2)$ & 0.047 \\
\hline $\begin{array}{l}\text { Cognitive function } \\
\text { (no. of errors) }\end{array}$ & $8.6(8.0)$ & $8.7(8.2)$ & $6.9(5.9)$ & 0.325 \\
\hline
\end{tabular}

${ }^{a}$ Euhydrated: urine specific gravity < 1.020; slightly hypohydrated: urine specific gravity 1.020-1.029; very hypohydrated: urine specific gravity $\geq 1.030$.

${ }^{b} \mathrm{P}$-values in bold indicate significant differences between all groups at $\mathrm{P}<0.05$

compared with the slightly hypohydrated group.

${ }^{\mathrm{a}}$ Compared with the very hypohydrated group).

Values shown are means (standard deviations). 


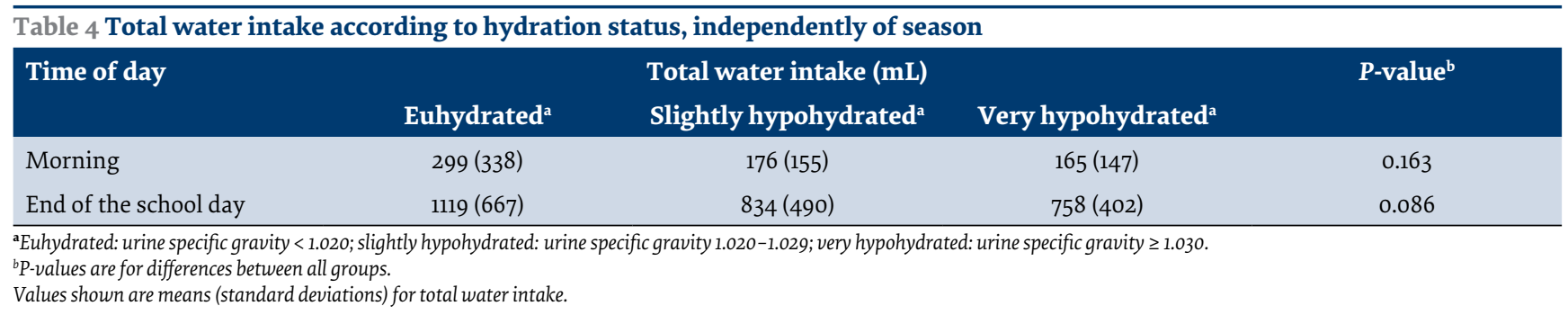

needs (27) and relying on thirst alone may not be enough to ensure adequate total water intake and body hydration.

Although it has been suggested that children living in hot environments are prone to chronic hypohydration (9), our data do not support or suggest chronic voluntary hypohydration. However, data from other studies suggest that day-to-day intrapersonal variability in water intake is probably quite low (28) and morning values of urine specific gravity have very good repeatability over 5 consecutive days (25). Therefore, it cannot be totally rejected that the data collected in our study may provide an indication of fluid drinking behaviour over time. Furthermore, our results can provide a stimulus for design and implementation of effective schoolbased interventions to promote appropriate drinking behaviour, especially in warm weather. For instance, it has been reported that children drink more water if they are allowed water bottles on their desk (29). Moreover, intervention programmes or school-based education campaigns have been found to be effective in modifying drinking behaviour and improving hydration status $(23,30)$.

Hypohydration in our study was associated with effects on subjective feelings. Hypohydrated students felt less alert and less able to concentrate during school time. These results agree with the findings of a previous study in men (5). It has also been reported that dehydration may affect mood state with high levels of hydration linked with high levels of vigour in children (11) and adults (31). These findings are important because negative feelings may have an adverse effect on the ability of adolescents to concentrate during class time and to perform well at school.

The impairment of these important aspects of cognitive function such as concentration and alertness, due to hypohydration, indicate that they may alter cognitive performance. Previous studies in children, reported a beneficial effect of hydration on short-term memory $(9,11)$. However, our results did not show any difference between hydrated and hypohydrated students in cognitive performance. This could be attributed either to the significant difference in group size (we had very few euhydrated students compared with many hypohydrated students), or to a lack of sensitivity of the test used in the study. However, other studies have also shown a lack of association between hydration status and cognitive test scores $(11,32)$. It has been suggested that the relationship between hydration levels and cognitive outcomes may not be totally linear, since hypohydration seems to affect some cognitive performance but not others (11).

We based hydration status on measured urine specific gravity. Although urine specific gravity is not the gold standard to assess hydration, it can be easily measured and is not invasive as is plasma osmolality. For practical reasons, plasma osmolality could not be measured in a school environment. Urine specific gravity data can provide useful and valuable information on hydration status in free-living conditions (33), which was pertinent to the aim of our study. The participants provided a sample of first morning urine which is well accepted for setting urine concentration threshold to assess hydration status (34). The second sample was obtained at the end of the school day before lunch. This time point has been shown to have a good diagnostic ability for detecting hypohydration in children (35).

A limitation of our study was that we did not measure physical activity during the school day. Therefore, we do not know if there were seasonal variations in physical activity levels during the school hours and how these variations could affect the hydration status of the adolescents. Another limitation is that the total water intake was based on self-reported food-and-fluid record. We do not know if the students were able to accurately self-assess, even though the procedure was fully explained.

Future research should focus on demonstrating effective measures to improve the hydration status of students during school time. Educational measures should be taken to promote proper drinking behaviour and improve hydration in adolescents both in Cyprus and internationally, which can positively affect not only concentration and school performance, but overall health as well.

Funding: This study was funded by the European Hydration Institute.

Competing interests: None declared. 


\section{Variations saisonnières dans la prévalence de l'hypohydratation chez les adolescents au cours de la journée d'école à Chypre}

\section{Résumé}

Contexte : Il existe peu de données factuelles sur l'état d'hydratation des adolescents et ses variations au cours des saisons et de la journée.

Objectifs : La présente étude avait pour objectif d'évaluer les variations dans l'état d'hydratation et les apports en eau chez les adolescents à Chypre, entre l'hiver et l'été et entre le matin et la fin de la journée d'école. Les ressentis subjectifs et les fonctions cognitives liés à l'hypohydratation ont également été examinés.

Méthodes : 53 adolescents (39 garçons) d'âge moyen 15,1 ans (écart type : 1,9) ont été inclus dans l'étude. Les participants ont fourni des échantillons d'urine, passé un test de fonctions cognitives et rempli un questionnaire sur leurs ressentis subjectifs, à l'arrivée à l'école et à la fin de la journée. Les données ont été recueillies en hiver et en été en 2016-2017. Le niveau d'hydratation a été déterminé par la mesure de la densité de l'urine. Les fonctions cognitives ont été évaluées au moyen d'un test de barrage de symboles. Les apports totaux en eau ont été estimés à partir d'un journal où les participants notaient leur prise d'aliments et de liquides.

Résultats: Une forte prévalence de l'hypohydratation, allant de $72 \%$ à $94 \%$, a été observée aux deux saisons. L'hypohydratation allait de pair avec des ressentis de concentration et de vigilance diminuées $(p=0,008$ et $p=0,047$, respectivement). La densité de l'urine chez les adolescents était significativement plus élevée en hiver qu'en été : $1,026$ (écart type : 0,007) contre 1,023 (écart type : 0,007), respectivement ( $p=0,002)$. L'état d'hydratation n'était corrélé ni avec les fonctions cognitives, ni avec les apports totaux en eau.

Conclusions : Les liens entre la forte prévalence de l'hypohydratation et les ressentis de diminution de la concentration et de la vigilance chez les adolescents portent à croire que des mesures sont nécessaires en milieu scolaire afin d'encourager des apports en liquides satisfaisants et d'améliorer l'hydratation.

$$
\begin{aligned}
& \text { انتشار الجفاف في صفوف المر اهقين أثناء اليوم الدراسي في قبرص: التغيرات الموسمية } \\
& \text { بينولبي ستافرينو، كريستفورس جيانكي، إليني آندرو، جورج آفاميس } \\
& \text { الخالاصة } \\
& \text { الخلفية: لا يوجد سوى قدر قليل من الدلائل بشأن حالة الإماهة في المراهقين و التغيرات الموسمية والزمنية. }
\end{aligned}
$$

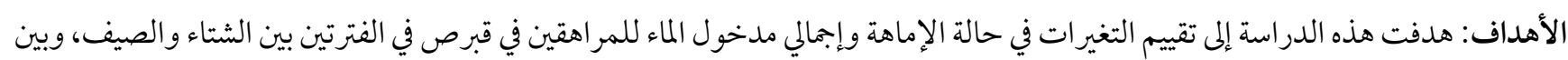

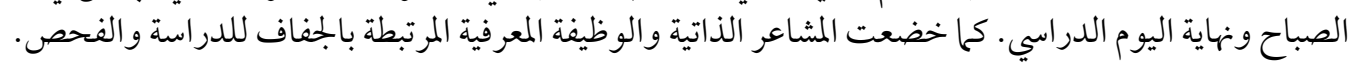

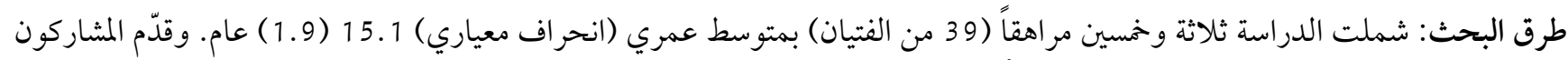

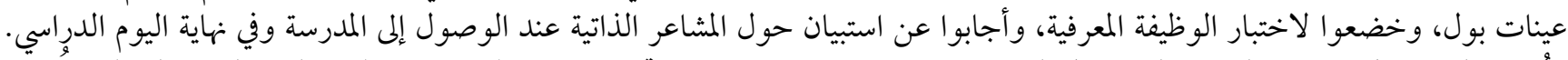

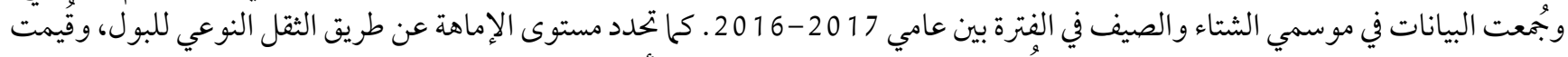

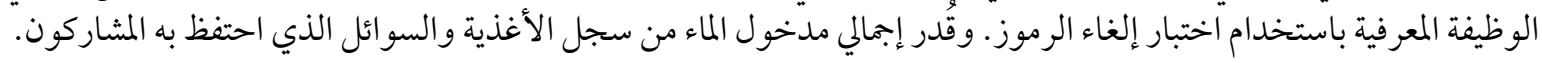

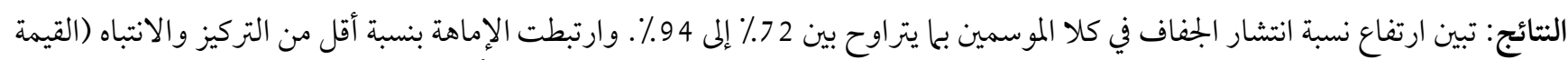

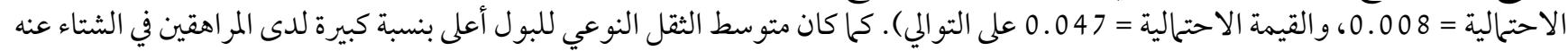

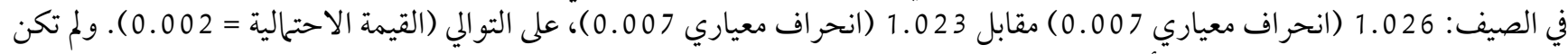

$$
\begin{aligned}
& \text { حالة الإماهة مرتبطة بالوظيفة المعرفية أو إجمالي مدخول المعاء الماءل }
\end{aligned}
$$

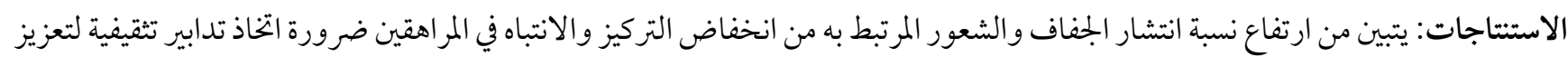

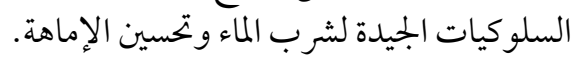

\section{References}

1. Jéquier E, Constant F. Water as an essential nutrient: the physiological basis of hydration. Eur J Clin Nutr. 2010;64(2):115-23. https://doi.org/10.1038/ejcn.2009.111

2. Malisova O, Athanasatou A, Pepa A, Husemann M, Domnik K, Braun H, et al. Water intake and hydration indices in healthy uropean adults: The European Hydration Research Study (EHRS). Nutrients. 2016;8(4):204. https://doi.org/10.3390/nu8040204

3. Sawka MN, Burke LM, Eichner ER, Maughan RJ, Montain SJ, Stachenfeld NS. American College of Sports Medicine position stand. Exercise and fluid replacement. Med Sci Sports Exerc. 2007;39(2):377-90. https://doi.org/10.1249/mss.obo13e31802ca597 
4. Maughan RJ. Impact of mild dehydration on wellness and on exercise performance. Eur J Clin Nutr. 2003;57(S2):S19-23. https:// doi.org/10.1038/sj.ejcn.1601897

5. Shirreffs SM, Merson SJ, Fraser SM, Archer DT. The effects of fluid restriction on hydration status and subjective feelings in man. Br J Nutr. 2004 ;91(6):951-8. https://doi.org/10.1079/BJN20041149

6. Pross N, Demazières A, Girard N, Barnouin R, Santoro F, Chevillotte E, et al. Influence of progressive fluid restriction on mood and physiological markers of dehydration in women. Br J Nutr. 2013;109(02):313-21. https://doi.org/10.1017/S0007114512001080

7. Wittbrodt MT, Millard-Stafford M. Dehydration impairs cognitive performance. Med Sci Sport Exerc. 2018;50(11):2360-8. http//:doi.org/10.1249/MSS.0000000000001682

8. Piil JF, Lundbye-Jensen J, Christiansen L, Ioannou L, Tsoutsoubi L, Dallas CN, et al. High prevalence of hypohydration in occupations with heat stress - perspectives for performance in combined cognitive and motor tasks. PLoS One. 2018;13(10):1-20. http//:doi.org/10.1371/journal.pone.0205321

9. Bar-David Y, Urkin J, Kozminsky E. The effect of voluntary dehydration on cognitive functions of elementary school children. Acta Paediatr. 2005;94(11):1667-73. http//:doi.org/10.1080/08035250500254670

10. Edmonds CJ, Burford D. Should children drink more water? The effects of drinking water on cognition in children. Appetite. 2009;52(3):776-9. http//:doi.org/10.1016/j.appet.2009.02.010

11. Fadda R, Rapinett G, Grathwohl D, Parisi M, Fanari R, Calò CM, et al. Effects of drinking supplementary water at school on cognitive performance in children. Appetite. 2012;59(3):730-7. http//:doi.org/10.1016/j.appet.2012.07.005

12. Bonnet F, Lepicard EM, Cathrin L, Letellier C, Constant F, Hawili N, et al. French children start their school day with a hydration deficit. Ann Nutr Metab. 2012;60(4):257-63. http//:doi.org/ 10.1159/000337939

13. Kempton MJ, Ettinger U, Foster R, Williams SCR, Calvert GA, Hampshire A, et al. Dehydration affects brain structure and function in healthy adolescents. Hum Brain Mapp. 2011;32(1):71-9. http//:doi.org/ 10.1002/hbm.20999

14. Maughan RJ, Watson P, Shirreffs SM. Implications of active lifestyles and environmental factors for water needs and consequences of failure to meet those needs. Nutr Rev. 2015;73 (Suppl 2):130-40. http//:doi.org/ 10.1093/nutrit/nuv051

15. Edmonds CJ, Crosbie L, Fatima F, Hussain M, Jacob N, Gardner M. Dose-response effects of water supplementation on cognitive performance and mood in children and adults. Appetite. 2017;108:464-70. http//:doi.org/ 10.1016/j.appet.2016.11.011

16. Aphamis G, Stavrinou PS, Andreou E, Giannaki CD. Hydration status, total water intake and subjective feelings of adolescents living in a hot environment, during a typical school day. Int J Adolesc Med Health. 2019;0(0):2-8. http//:doi.org/10.1515/ ijamh-2018-0230 .

17. Flint A, Raben A, Blundell JE, Astrup A. Reproducibility, power and validity of visual analogue scales in assessment of appetite sensations in single test meal studies. Int J Obes Relat Metab Disord. 2000;24(1):38-48. http//:doi.org/10.1038/sj.ijo.0801083

18. Lowery N, Ragland JD, Gur RC, Gur RE, Moberg PJ. Normative data for the symbol cancellation test in young healthy adults. Appl Neuropsychol. 2004;11(4):218-21. http//:doi.org/10.1207/s15324826an1104_8

19. Malisova O, Bountziouka V, Panagiotakos D区, Zampelas A, Kapsokefalou M. Evaluation of seasonality on total water intake, water loss and water balance in the general population in Greece. J Hum Nutr Diet. 2013;26(SUPPL.1):90-6. http//:doi.org/ 10.1111/ jhn.12077

20. Armstrong L, Johnson E, Armstrong LE, Johnson EC. Water intake, water balance, and the elusive daily water requirement. Nutrients. 2018;10(12):1928. http//:doi.org/ 10.3390/nu10121928

21. Henry CJK, Lightowler HJ, Al-Hourani HM. Physical activity and levels of inactivity in adolescent females ages 11-16 years in the United Arab Emirates. Am J Hum Biol. 2004;16(3):346-53. http//:doi.org/ 10.1002/ajhb.20022

22. Al-Mohannadi AS, Moahhed GA. The effect of weather conditions on the seasonal variation of physical activity. Aspetar Sport Med J. 2015;4:228-31.

23. Carter JM, Loney T, Blacker SD, Nicholson GF, Wilkinson DM. Hydration status of Arabic adolescents and young men: measurement, evaluation, and a school-based initiative to improve drinking behavior. Int J Sport Nutr Exerc Metab. 2012;22(4):257-66. http//:doi.org/ 10.1123/ijsnem.22.4.257

24. Gordon RE, Kassier SM, Biggs C. Hydration status and fluid intake of urban, underprivileged South African male adolescent soccer players during training. J Int Soc Sports Nutr. 2015;12(1):21. http//:doi.org/ 10.1186/s12970-015-0080-0

25. Logan-Sprenger HM, Spriet LL. The acute effects of fluid intake on urine specific gravity and fluid retention in a mildly dehydrated state. J Strength Cond Res. 2013;27(4):1002-8. http//:doi.org/ 10.1519/JSC.obo13e31826052c7

26. Millard-Stafford M, Wendland DM, O’Dea NK, Norman TL. Thirst and hydration status in everyday life. Nutr Rev. 2012;70 Suppl 2:S147-51. http//:doi.org/ 10.1111/j.1753-4887.2012.00527.x

27. Arnaoutis G, Kotsis YP, Tsekouras YE, Makrillos M, Bardis CN, Kavouras SA. Ad libitum fluid intake does not prevent dehydration in suboptimally hydrated young soccer players during a training session of a summer camp. Int J Sport Nutr Exerc Metab. 2013;23(3):245-51. http//:doi.org/ 10.1123/ijsnem.23.3.245

28. Gibson S, Shirreffs SM. Beverage consumption habits "24/7" among British adults: association with total water intake and energy intake. Nutr J. 2013;12(42):9. http//:doi.org/ 10.1186/1475-2891-12-9 
29. Kaushik A, Mullee MA, Bryant TN, Hill CM. A study of the association between children's access to drinking water in primary schools and their fluid intake: Can water be "cool" in school? Child Care Health Dev. 2007;33(4):409-15. http//:doi.org/ 10.1111/j.1365-2214.2006.00721.X

30. Kavouras SA, Arnaoutis G, Makrillos M, Garagouni C, Nikolaou E, Chira O, et al. Educational intervention on water intake improves hydration status and enhances exercise performance in athletic youth. Scand J Med Sci Sport. 2012;22(5):684-9. http//:doi. org/ 10.1111/j.1600-0838.2011.01296.x

31. D'anci KE, Vibhakar A, Kanter JH, Mahoney CR, Taylor HA. Voluntary dehydration and cognitive performance in trained college athletes. Percept Mot Skills. 2009;109(1):251-69. http//:doi.org/ 10.2466/PMS.109.1.251-269

32. Trinies V, Chard AN, Mateo T, Freeman MC. Effects of water provision and hydration on cognitive function among primary-school pupils in Zambia: a randomized trial. PLoS One. 2016;11(3):e0150071. http//:doi.org/ 10.1371/journal.pone.0150071

33. Perrier E, Vergne S, Klein A, Poupin M, Rondeau P, Le Bellego L, et al. Hydration biomarkers in free-living adults with different levels of habitual fluid consumption. Br J Nutr. 2013;109(9):1678-87. http//:doi.org/ 10.1017/Sooo7114512003601

34. Cheuvront SN, Kenefick RW, Zambraski EJ. Spot Urine concentrations should not be used for hydration assessment: a methodology review. Int J Sport Nutr Exerc Metab. 2015;25(3):293-7. http//:doi.org/ 10.1123/ijsnem.2014-0138

35. Kavouras SA, Johnson EC, Bougatsas D, Arnaoutis G, Panagiotakos DB, Perrier E, et al. Validation of a urine color scale for assessment of urine osmolality in healthy children. Eur J Nutr. 2016;55(3):907-15. http//:doi.org/ 10.1038/ejcn.2016.218 